\title{
EFEKTIVITAS PENGGUNAAN E-TILANG TERHADAP PELANGGARAN LALU LINTAS DI POLRES MAGELANG
}

\author{
Lutfina Zunia Apriliana \\ Prodi Magister Ilmu Hukum, Fakultas Hukum, Universitas Diponegoro, \\ Semarang \\ e-mail: finaapriliana@gmail.com \\ Nyoman Serikat Putra Jaya \\ Fakultas Hukum, Universitas Diponegoro, Semarang \\ e-mail: putrajaya1984@yahoo.co.id
}

\begin{abstract}
ABSTRAK
Pembangunan infrastruktur angkutan jalan memiliki peranan penting dalam menunjang aktifitas perekonomian, namun pada sisi lain melahirkan berbagai permasalahan menyangkut pelanggaran hukum lalu lintas, kecelakaan, ketidak teraturan pengguna jalan, dan kemacetan. Penerapan e-tilang merupakan pilihan yang efektif yang mencapai sasaran dalam pelaksanaan tilang kepada pelanggar peraturan lalu lintas walaupun belum dapat dikatakan bahwa e-tilang ini efektif karena belum semua masyarakat di Indonesia menguasai teknologi. Penelitian ini menggunakan metode yuridis empiris untuk menjawab apakah ke efektivitasan penggunaan e-tilang di Polres Magelang. Hasil dari penelitian ini menunjukan penggunaan aplikasi e-tilang terlihat belum efektif karena belum memenuhi kelima indikator efektivitas yang dikemukakan oleh Stees. Indikator tersebut adalah produktivitas, kemampuan adaptasi kerja, kepuasan kerja, kemampuan berlaba dan pencarian sumber daya. Terdapat faktor penghambat yang mempengaruhi efektivitas aplikasi e-tilang, diantaranya adalah sumber daya manusia, intensitas sosialisasi etilang, mekanisme pelayanan aplikasi e-tilang serta sarana dan prasarana.
\end{abstract}

Kata Kunci: Efektivitas, E-Tilang, Lalu Lintas, Polres Magelang.

\begin{abstract}
The construction of road transport infrastructure has an important role in supporting economic activity, but on the other hand it creates various problems regarding traffic law violations, accidents, road user irregularities and congestion. The implementation of e-Tilang is an effective choice that reaches the target in the implementation of Tilang to violators of traffic regulations although it cannot be said that this e-Tilang is effective because not all communities in Indonesia have mastered the technology. This study uses juridical empirical methods to answer whether the effectiveness of the use of e-Tilang in the Magelang Police Station. The results of this study indicate that the use of the e-Tilang application has not been effective because it has not fulfilled the five effectiveness indicators proposed by Stees. These indicators are productivity, work adaptability, job satisfaction, profitability and resource search. There are inhibiting factors that influence the effectiveness of e-Tilang
\end{abstract}


applications, including human resources, the intensity of e-Tilang socialization, the service mechanism of e-Tilang applications and facilities and infrastructure.

Keywords: Effectiveness, E-Tilang, Traffic, Magelang Police Station.

\section{Pendahuluan}

Pembangunan infrastruktur lalu lintas dan angkutan jalan yang dewasa ini tengah ditingkatkan oleh pemerintahan Jokowi-Jusuf Kalla, terutama pada beberapa daerah yang selama ini terisolasi memiliki peranan penting dalam menunjang aktifitas perekonomian masyarakat setempat. Dengan berkembanganya ekonomi masyarakat menjadikan alat transportasi sebagai kebutuhan pokok untuk mempermudah aktivitas sehari hari. Namun pada sisi lain meningkatnya intensitas kegiatan masyarakat di jalan raya tersebut melahirkan berbagai permasalahan terhadap keamanan, keselamatan, ketertiban dan kelancaran lalu lintas (Kamseltibcarlantas). Implikasi dari permasalahan itu antara lain menyangkut pelanggaran hukum lalu lintas, kecelakaan lalu lintas, ketidak teraturan pengguna jalan, dan kemacetan lalu lintas di jalan.

Untuk mencegah hal tersebut diatas maka diperlukanya aparat penegak hukum yang memiliki wewenang dan tanggung jawab atas Keamanan dan Ketertiban Negara, ialah Kepolisian Negara Republik Indonesia (POLRI) selaku alat negara penegak hukum, pelindung, pengayom dan pelayan masyarakat sebagaimana tertuang dalam tugas pokoknya yaitu pada pasal 13 UndangUndang Nomor 2 Tahun 2002 tentang Kepolisian Negara Republik Indonesia.

Satuan Lalu Lintas (Satlantas) adalah unsur pelaksana Polres yang dalam tugasnya bertanggung jawab menyelenggarakan tugas kepolisian mencakup di bidang lalu lintas yang merupakan penjabaran kemampuan teknis profesional yang meliputi pengaturan, penjagaan, pengawalan, patroli, pendidikan masyarakat dan rekayasa lalu lintas, registrasi dan identifikasi pengemudi atau kendaraan bermotor, penyidikan kecelakaan lalu lintas dan penegakkan hukum dalam bidang lalu lintas, guna memelihara keamanan, ketertiban dan kelancaran lalu lintas sebagaimana diatur dalam Pasal 12 Undang-undang Nomor 22 Tahun 2009 tentang Lalu Lintas dan Angkutan Jalan dan juga mendukung upaya memajukan kesejahteraan umum sebagaimana diamanatkan juga pada pembukaan Undang-undang Dasar Negara Republik Indonesia Tahun 1945.

Salah satu Upaya yang di lakukan Anggota Kepolisian Satuan Lalu Lintas dalam pelaksanaaan tugasnya adalah pembinaan lalu lintas jalan raya, sebagai upaya preventif dalam mencegah ketidaknyamanan dan ancaman keselamatan dalam berkendara, salah satu contoh perlengkapan yang harus ada ketika berkendara yaitu Helm SNI (Standar Nasional Indonesia). Disamping itu para pengendara diwajibkan membawa serta kelengkapan administrasi kendaraan berupa STNK dan bukti kecakapan/keterampilan berkendara berupa Surat Ijin Mengemudi. Bagi pengendara yang tidak memenuhi kriteria aman dalam berkendara serta tidak membawa kelengkapan yang seharusnya ada ketika berkendara maka akan di kenakan pelanggaran lalu lintas yang selanjutnya akan dilakukan 
penindakan pelanggaran oleh Satuan Lalu Lintas (Junef, 2014).

Penindakan pelanggaran lalu lintas dilakukan oleh petugas kepolisian baik secara edukatif maupun yuridis, hal ini sesuai dengan perannya, dalam Pasal 1 ayat 2 Peraturan Pemerintah No. 80 Tahun 2012 menyatakan bahwa penindakan pelanggaran lalu lintas dan angkutan jalan adalah rangkaian tindakan yang dilaksanakan oleh penyidik Kepolisian Negara Republik Indonesia atau Penyidik Pegawai Negeri Sipil di bidang Lalu Lintas dan Angkutan Jalan terhadap pelanggaran Lalu Lintas dan Angkutan Jalan.

$$
\text { Bukti Pelanggaran atau }
$$
disingkat Tilang adalah hukuman berupa denda yang dikenakan oleh polisi kepada pengguna jalan yang melanggar peraturan. Tilang diharapkan mampu menangani permasalahan berlalu lintas. Ada tiga fungsi utama tilang yaitu: (1).Sebagai surat panggilan ke Pengadilan Negeri; (2). Sebagai pengantar untuk membayar denda ke Bank/Panitera; dan (3). Sebagai tanda penyitaan atas barang bukti yang disita, seperti SIM, STNK atau kendaraan.

Sejalan dengan Kebijakan Kepala Kepolisian Negara Republik Indonesia 13 Juli 2016 lalu, Jenderal Polisi Prof. Drs H M Tito Karnavian MA, PhD, mengusung terwujudnya Polri yang makin profesional, modern, dan terpercaya, maka peningkatan pelayanan publik yang harus berbasis teknologi informasi (TI), kemajuan teknologi pada zaman era globalisasi ini akan membantu penegakan hukum dalam mengatasi permasalahan pelanggaran khususnya Pelanggaran berkendara lalu lintas jalan raya.
Tilang elektronik yang biasa disebut E-tilang adalah digitalisasi proses tilang, dengan memanfaatkan teknologi informasi" diharapkan keseluruhan proses tilang menjadi inovasi yang dapat membantu pihak kepolisian dalam manajemen penindakan serta Pembayaran Denda Pelanggaran Lalu Lintas. Dengan sistem E-tilang, pelanggar hanya membayar denda pada pasal yang dilanggar melalui rekening Bank milik pelanggar (Setiyanto, Gunarto, \& Wahyuningsih, 2017). Setelah mendapat notifikasi pembayaran denda tilang, pelanggar dapat langsung menunjukan kepada petugas bahwa tilang sudah terbayar, kemudian pelanggar dapat mengambil barang sitaan dan melanjutkan perjalanan. Hasil putusan sidang tilang tentang denda yang harus dibayar oleh pelanggar menunggu pelaksanaan sidang. Saat vonis di tetapkan oleh pengadilan tentang nominal denda tilang, pelanggar akan mendapatkan pemberitahuan berupa notifikasi dan pengembalian denda yang sudah di bayar pelanggar melalui rekening bank milik pelanggar (Junef, 2014).

Penerapan E-tilang merupakan langkah baik yang diambil kepolisian dalam mewujudkan pelayanan publik agar lebih efektif, efisien, transparan dan akuntabel. Mengedepankan pelayanan yang profesional guna meningkatkan kepercayaan masyarakat terhadap instansi Polri serta meningkatkan peran serta masyarakat dalam penegakan hukum khususnya dalam penindakan pelanggaran lalu lintas dimana masyarakat yang menjadi subjek hukum dari terjadinya sebuah pelanggaran di jalan raya (Setiyanto, Gunarto, \& Wahyuningsih, 2017). 
Akan tetapi, pada kenyataanya penggunaan Aplikasi E-Tilang di Wilayah Hukum Polres Magelang masih terbilang minim dibandingkan pengunaan tilang manual, padahal sejatinya e-tilang lebih memudahkan para pelanggar untuk menyelesaikan permasalahan hukum yang di hadapinya dengan reformasi birokrasi yang efektif serta kepastian hukum terhadap denda tilang yang di dapatkan oleh pelanggar. Kepastian hukum merupakan faktor yang paling menjadi sorotan dalam penindakan pelanggaran hukum, karena setiap pelanggar akan di kenakan sanksi denda yang sesuai dengan nominal berdasarkan Undang-Undang Nomor 22 Tahun 2009 tentang Lalu Lintas dan Angkutan Jalan, yang telah disahkan DPR-RI pada tanggal 22 Juni 2009.

Mengingat penelitian mengenai penggunaan e-tilang sebelumya telah dilakukan seperti penerapan sanksi denda e-tilang di Polres Rembang (Setiyanto, Gunarto, \& Wahyuningsih, 2017) dan inovasi program e-tilang sebagai peningkatan pelayanan publik di Polres Kediri (Salsabila, 2018). Berdasarkan penelitian sebelumnya, terdapat perbedaan fokus penelitian yang akan di lakukan oleh penulis dengan penelitian yang sudah ada. Penelitian ini sama-sama bertemakan e-tilang, namun penulis lebih menekankan indicator-indikator penghambat penggunaan e-tilang di Polres Magelang, sehigga membuat pembahasan mengenai e-tilang ini menjadi selalu penting dan aktual untuk dilakukan pengkajian lanjut.

\section{Perumusan Masalah}

Rumusan masalah berdasarkan uraian di atas yaitu: (1). Bagaimana efektivitas penggunaan e-tilang terhadap pelanggaran lalu lintas di Polres Magelang?; dan (2). Apa saja faktor-faktor yang mempengaruhi efektivitas aplikasi e-tilang dalam pembayaran denda pelanggaran lalu lintas di Polres Magelang?.

\section{Metode Penelitian}

Pada artikel ini, jenis penelitian yang digunakan bersifat doktrinal yakni metode penelitian yuridis empiris. Deskriptif analitis merupakan sifat spesifikasi penelitian yang digunakan oleh penulis, karena spesifikasi penelitian ini menggambarkan serta mendeskripsikan permasalahan dari obyek yang sedang diteliti serta faktor yang mempengaruhinya (Suteki \& Taufani, 2018).

Data primer serta data sekunder dipergunakan dalam penulisan artikel ini. Data primer ialah data yang diperoleh melalui kegiatan wawancara responden di lapangan. Data sekunder ialah data tidak langsung diperoleh dari sumber obyek penelitian (Suteki \& Taufani, 2018). Dalam mengumpulkan data primer pada penelitian ini yakni melalui kegiatan wawancara terhadap responden, sedangkan teknik yang digunakan untuk mengumpulkan data sekunder ialah melalui melakukan studi pustaka (library research) ataupun studi dokumenter. Data yang diperoleh saat wawancara terhadap responden serta bahan-bahan hukum dipelajari dan dianalisis untuk memberikan gambaran-gambaran tentang topic penelitian sehingga membantu penulis membuat suatu kesimpulan yang benar.

\section{Pembahasan}


Efektivitas Penggunaan E-Tilang Terhadap Pelanggaran Lalu Lintas Di Polres Magelang

Aplikasi e-tilang merupakan inovasi dari Korlantas Polri dalam meningkatan pelayanan pembayaran denda pelanggaran lalu lintas berbasis TI (Teknologi Informasi), pembuatan aplikasi e-tilang terintegrasi dengan instansi terkait yang telah disepakati dan dikoordinasikan antara Korps Lalu Lintas (Korlantas) Kepolisian RI., Mahkamah Agung RI., Kejaksaan Agung RI., dan PT. Bank Rakyat Indonesia (Persero) Tbk. Aplikasi tersebut terdiri dari 26 kolom yang diisi oleh masing-masing instansi dengan kewenangan masing masing dengan proses pengelolaan data perkara pelanggaran lalu lintas / tilang dengan menggunakan aplikasi tilang online (etilang) (Chusminah, Haryati, \& Kristiani, 2018).

Pelaksanaan aplikasi e-tilang di mulai pada bulan November tahun 2016 dan baru terealisasi di Polres Magelang Kabupaten pada bulan April tahun 2017. Dengan penerapan etilang, akan sangat membantu masyarakat (pelanggar) untuk melakukan pembayaran denda tilang melalui jasa perbankan (atm, teller, ebanking) dan akan memudahkan pengelolaan data perkara pelanggaran lalu lintas / tilang baik bagi Polri, Makamah Agung RI., maupun Kejaksaan RI. Disamping itu data penyelesaian perkara tilang menjadi transparan dan akuntabel sehingga tercapai tertib adminsitrasi dalam pengelolaan data perkara tilang, bebas pungli dan penerimaan negara dari hasil penanganan perkara tilang menjadi lebih optimal.

Namun, berdasarkan data yang penulis dapatkan di polres magelang kabupaten pada kenyataanya penggunaan aplikasi e-tilang di wilayah hukum polres magelang kabupaten masih sangatlah minim, berikut merupakan data 2 tahun terakhir penggunaan aplikasi e-tilang di polres magelang.

Tabel 1. Data Dakgar Menggunakan Tilang Manual E E-Tilang Tahun 2017

\begin{tabular}{|c|c|r|r|c|c|}
\hline NO & BULAN & $\begin{array}{c}\text { HASIL } \\
\text { DAKGAR }\end{array}$ & $\begin{array}{c}\text { SIDANG } \\
\text { MANUAL }\end{array}$ & E TILANG & KET \\
\hline & \multicolumn{1}{|c|}{2} & 3 & 4 & 5 & 6 \\
\hline 1 & JANUARI & 3,959 & 3,959 & 0 & \\
\hline 2 & FEBRUARI & 4,427 & 4,427 & 0 & \\
\hline 3 & MARET & 4,013 & 4,013 & 0 & \\
\hline 4 & APRIL & 2,857 & 2,460 & 397 & \\
\hline 5 & MEI & 2,217 & 1,990 & 227 & \\
\hline 6 & JUNI & 3,012 & 2,534 & 478 & \\
\hline 7 & JULI & 3,060 & 2,317 & 743 & \\
\hline 8 & AGUSTUS & 6,509 & 5,337 & 1,172 & \\
\hline 9 & SEPTEMBER & 2,030 & 1,745 & 285 & \\
\hline 10 & OKTOBER & 7,900 & 5,339 & 2,561 & \\
\hline 11 & NOVEMBER & 6,252 & 4,616 & 1,636 & \\
\hline 12 & DESEMBER & 241 & 241 & 0 & \\
\hline & JUMLAH & 46,477 & 38,978 & 7,499 & \\
\hline
\end{tabular}

Sumber: Baur Min Tilang Polres Magelang Kabupaten 2018.

Tabel 2. Data Dakgar Menggunakan

Tilang Manual E E-Tilang Tahun 2018

\begin{tabular}{|c|c|c|c|c|c|}
\hline NO & BULAN & $\begin{array}{c}\text { HASIL } \\
\text { DAKGAR }\end{array}$ & SIDANG MANUAL & E TILANG & KET \\
\hline & 2 & 3 & 4 & 5 & 6 \\
\hline 1 & JANUARI & 8,499 & 6,249 & 2,250 & \\
\hline 2 & FEBRUARI & 5,950 & 4,820 & 1,130 & \\
\hline 3 & MARET & 7,102 & 5,362 & 1,740 & \\
\hline 4 & APRIL & 4,420 & 3,430 & 990 & \\
\hline 5 & MEI & 4,187 & 3,317 & 870 & \\
\hline 6 & JUNI & 801 & 291 & 510 & \\
\hline 7 & JULI & 456 & 96 & 360 & \\
\hline 8 & AGUSTUS & 4,651 & 3,331 & 1,320 & \\
\hline 9 & SEPTEMBER & 4,489 & 3,079 & 1,410 & \\
\hline 10 & OKTOBER & 3,557 & 2,507 & 1,050 & \\
\hline 11 & NOVEMBER & 4,448 & 3,188 & 1,260 & \\
\hline 12 & DESEMBER & 397 & 397 & 0 & \\
\hline & JUMLAH & 48,957 & 36,067 & 12,890 & \\
\hline
\end{tabular}

Sumber: Baur Min Tilang Polres Magelang Kabupaten 2018

Dari data tabel-tabel di atas bahwasanya hanya kurang lebih 20\% penggunaan aplikasi e-tilang yang di terapkan sebagai penindakan pelanggaran lalu lintas di polres magelang kabupaten, mengingat 
aplikasi ini merupakan inovasi dari korlantas polri agar terciptanya kinerja dengan birokrasi yang memudahkan petugas penindak dan pelanggar.

Membahas tentang efektivitas penggunaan aplikasi e-tilang dalam pembayaran denda pelanggaran lalu lintas penulis menganalisis dengan menggunakan teori efektivitas yang di kemukakan oleh Stees dimana terdapat 5 indikator dalam pengukuran efektivitas suatu program, diantaranya: (1).Produktivitas; (2).Kemampuan Adaptasi Kerja; (3).Kepuasan Kerja; (4).Kemampuan Berlaba; dan (5).Pencarian Sumber Daya (Chusminah, Haryati, \& Kristiani, 2018).

Indikator pertama adalah produktivitas yang merupakan kuantitas atau volume dari produk atau jasa pokok yang dihasilkan organisasi. Dapat diukur menurut tiga tingkatan yakni tingkatan individual, kelompok dan keseluruhan organisasi. Indikator produktivitas dari segi organisi dapat dilihat dari segi keefektivitas suatu program, aplikasi etilang sudah beroperasi lebih dari dua tahun dan masih membutuhkan beberapa perubahan sistem yang mengatur mengenai embuatan blangko e-tilang kepada pelanggar (Rakhmadani, 2017).

Wawancara dilakukan Bersama Aipda Budi Sartono di Pos Lantas Borobudur Kabupaten Magelang pada 1 Maret 2019, menyebutkan yang menjadi persoalan yang di temukan adalah karena pengisian identitas yang harus dilaksanakan dua kali karena perlu di salin ke Blangko Biru sebelum pelanggar teregistrasi dengan e-tilang. Petugas sebagai pelaksana penggunaan aplikasi e-tilang pun merasa hal ini menyulitkan dan memakan waktu karena hal tersebut, dengan berbagai keluhan yang di sampaikan oleh petugas sebagai penindak ini menjadi alasan bahwa tilang konvensional lebih mudah untuk menyelesaikan perkara yang menjadi kewajiban dalam penindakan pelanggaran lalu lintas di jalan raya ketimbang menggunakan aplikasi etilang sebagai penindakan pelanggaran lalu lintas.

Fakta tersebut dapat kita tinjau dari angka penggunaan e-tilang dalam penindakan pelanggaran lalu lintas sebagai sarana pembayaran denda pelanggaran lalu lintas tahun 2018 yang masih berada pada angka 1.038, bila dibandingkan dengan angka pembayaran denda tilang manual (konvensional) yang terdapat di polres magelang. Apabila direkapitulasi, angka pembayaran denda pelanggaran lalu lintas tahunan yang menggunakan aplikasi e-tilang hanya sekitar 20\% pertahun, tentu hal tersebut merupakan sebuah angka yang sangat kecil bagi penggunaan sebuah aplikasi sebagai sarana pembayaran denda pelanggaran dalam instansi pemerintahan. Maka dari itu, apabila dilihat dari indikator produktivitas, aplikasi e-tilang belum memenuhi indikator karena penggunaan aplikasi e-tilang belum produktif dan masih cenderung menggunakan tilang konvensional di daerah magelang kabupaten.

Indikator ke dua adalah, kemampuan adaptasi kerja yang merupakan suatu kemampuan untuk mengubah atau merombak standarisasi prosedur operasinya apabila lingkungannya berubah pula, hal ini dimaksudkan untuk mencegah kebakuan terhadap rangsangan 
lingkungan (Chusminah, Haryati, \& Kristiani, 2018).

Aipda Budi Sartono juga menyampaikan dari segi penegakan hukum menggunakan aplikasi e-tilang yang dilaksanakan di Kabupaten Magelang petugas kepolisian tidak mampu beradaptasi dengan ketentuan penggunaan e-tilang sebagai sarana tindak pelanggaran, karena memiliki birokasi yang lebih rumit di bandingkan tilang konvesional dan petugas dalam penggunaan e-tilang di Polres Magelang tidak melaksanakan sesuai dengan SOP e-tilang menurut Peraturan Kepala Korps Lalu Lintas Kepolisian Negara Republik Indonesia No. 6 Tahun 2018 tentang Standar Operasional, Prosedur Penindakan Pelanggaran Lalu Lintas Dan Angkutan Jalan Dengan Surat Tilang Elektronik.

Pihak organisasi yang pada hal ini diwakili oleh Satuan Lantas Polres Magelang Kabupaten belum dapat melakukan adaptasi dan aplikasi terhadap program aplikasi e-tilang karena sebelum aplikasi tersebut diluncurkan, terlebih dahulu disiapkan sumber daya manusia yang bertanggung jawab atas aplikasi tersebut, yang mampu, mumpuni dan memiliki kualifikasi dalam hal teknologi informasi, serta memahami SOP pelaksanaan aplikasi yang pada akhirnya berakibat pada meningkatnya animo masyarakat untuk menggunakan aplikasi e-tilang sebagai sarana penindakan pelanggaran lalu lintas, sehingga dalam hal ini apabila dilihat dari indikator kemampuan adaptasi kerja satuan lantas polres magelang belum memenuhi indikator tersebut.

Indikator ke tiga adalah, kepuasan kerja yaitu indikator yang mengukur tingkat kesenangan yang dirasakan seseorang atas peranan atau pekerjaannya dalam organisasi. Tingkat rasa puas individu bahwa mereka mendapatkan imbalan yang setimpal dari bermacam-macam aspek situasi dimana mereka berada. Faktor kepuasan kerja ini tentunya menjadi suatu hal yang bersifat subjektif, setiap pelanggar memiliki penilaian sendiri terhadap pelayanan aplikasi e-tilang (Rakhmadani, 2017).

Dewasa ini, sangat jarang adanya pelanggar yang menggunnakan e-tilang terhadap penindakan pelanggaran lalu lintas. Hasil wawancara bersama Bapak Dewantoro, pelanggar yang menggunakan e-tilang pada 28 April 2019 merasa puas karena dengan menggunakan aplikasi e-tilang, pelanggar tersebut dapat menghemat waktu, tenaga dan biaya serta dapat menyelesaikan perkara di tempat.

Namun disisi lain, penulis juga melakukan wawancara bersama Ibu Siti Rahmawati sebagai pelanggar yang masih membayara denda dengan menggunakan tilang manual di polres magelang kabupaten pada tanggal 28 April 2019, pelanggar tersebut mengaku belum merasakan pelayanan dan pemberlakuan aplikasi e-tilang di Polres Magelang Kabupaten, tidak adanya sosialisasi dan tawaran untuk penyelesaian pembayaran denda dengan menggunakan aplikasi e-tilang di polres tersebut, pelanggar hanya dianjurkan untuk membayar denda dan mengambil barang bukti yang nanti di proses di Kejaksaan Agung. Maka dari itu, pelanggar yang tidak menggunakan pelayanan aplikasi etilang dikarenakan belum adanya sosialisasi dan penerapan secara menyeluruh di Polres Magelang, 
artinya bahwa petugas kepolisian selaku penindak pelanggar lalu lintas belum melaksanakan tugas sesuai dengan SOP dan belum adanya pemberdayaan aplikasi e-tilang, sehingga kemudahan dan manfaat pelayanan aplikasi e-tilang sebagai sarana pembayaran denda pelanggaran lalu lintas tidak berdampak secara simultan kepada masyarakat kabupaten magelang dan minimnya eksistensi dari pelayanan aplikasi e-tilang, sehingga apabila indikator kepuasan kerja ingin dijadikan sebagai acuan tingkat efektivitas suatu program, maka indikator kepuasan kerja harus disandingkan dengan indikatorindikator lain yang memperkuat hasil penulisan penulis.

Indikator ke empat adalah kemampuan berlaba, adalah kemampuan untuk mendapatkan penghasilan atas penanaman modal yang dipakai untuk menjalankan organisasi dilihat dari sudut pandang si pemilik. Bahwa pada tahun 2018 transaksi yang menggunakan aplikasi e-ilang sebagai media pembayaran denda pelanggaran lalu lintas hanya sebesar 12.890 dari hasil jumlah dakgar e- tilang jika dibandingkan dengan pembayaran denda tilang manual sebesar 36,067 dari hasil jumlah dakgar tilang manual yang berati angka tersebut merupakan angka yang sangat kecil apabila dibandingkan dengan tilang manual di polres magelang kabupaten. Bahkan masyarakat kabupaten magelang lebih tertarik membayar denda pelanggaran lalu lintas melalui kejaksaan negeri karena pembayaran denda yang lebih murah dan sudah menjadi birokrasi yang sering di gunakan sebagai penyelesaian pembayaran denda pelanggaran lalu lintas di kabupaten magelang.

$$
\text { Indikator kelima adalah }
$$

pencarian sumber daya, yang merupakan kemampuan organisasi dalam mencari sumber daya yang diperlukan yang memiliki kemampuan yang mumpuni dalam bidang yang diperlukan. Pelayanan aplikasi e-tilang ini membutuhkan sarana yang tepat untuk meningkatkan ketertarikan penggunaan e-tilang dalam pembayaran denda pelanggaran lalu lintas, salah satunya adalah EDC (Electronic Data Capture). Sesuai dengan pasal 7 ayat 1 Peraturan Kepala Korps Lalu Lintas Kepolisian Negara Republik Indonesia Nomor 6 Tahun 2018 menyatakan bahwa penyidik atau penyidik pembantu sebagaiaman di maksud dalam pasal 6 melaksanakan penindakan pelanggaran lalu liintas tertentu dengan sistem e-tilang, menggunakan : (a).Surat tilang elektronik; (b).Telephone genggam sistem android (smartphone e-tilang); dan (c).Alat transaksi elektronik perbankan untuk penyetoran uang titipan denda secara elektronik melalui bank

Pada huruf c ini menekankan bahwa EDC sebagai sarana pelayanan aplikasi e-tilang dalam pembayaran denda perlu di hadirkan dalam setiap penggunaan aplikasi e-tilang namun kenyataanya, edc masih belum terdapat di setiap pos penindakan pelanggaran lalu lintas, hanya terdapat 1 pos dari 6 pos yang menggunakan EDC, hal ini perlu di perhatikan oleh pimpinan terhadap eksistensi penggunaan aplikasi e-tilang.

Dari kelima indikator diatas, belum ada satupun dari kelima indikator yang dapat dipenuhi oleh aplikasi e-tilang sebagai sarana pembayaran denda 
pelanggaran lalu lintas di polres magelang kabupaten sehingga penulis dapat menyimpulkan bahwa aplikasi e-tilang yang diterapkan di polres magelang kabupaten belum efektif dipakai sebagai sarana pembayaran denda pelanggaran lalu lintas di polres magelang kabupaten.

\section{Faktor-Faktor Yang Mempengaruhi Efektivitas E-Tilang Terhadap Pelanggaran Lalu Lintas Di Polres Magelang}

Dalam mewujudkan pelayanan e-tilang terhadap pembayaran denda pelanggaran lalu lintas yang baik, korlantas polri tentunya telah berupaya untuk meningkatkan pelayanan secara maksimal yang selanjutnya di terapkan di berbagai daerah termasuk daerah kabupaten magelang. Namun dalam mewujudkan hal tersebut, terdapat faktor penghambat yang mempengaruhi efektivitas aplikasi etilang, diantaranya adalah: (1).Sumber Daya Manusia; (2).Intensitas Sosialisasi E-tilang; (3).Mekanisme Pelayanan Aplikasi E-tilang; dan (4).Sarana dan Prasarana.

Dilihat dari aspek sumber daya manusia, dari sisi keduanya memiliki kekurangan. Dari sisi petugas penindak pelanggaran lalu lintas, petugas belum bisa menerapkan aplikasi e-tilang secara simultan karena motivasi dari petugas kepolisian untuk melayani dan mengayomi masyarakat sangatlah kurang, sehingga pemanfaatan aplikasi e-tilang tidak di laksanakan dengan baik. Yang kedua, dilihat dari sisi masyarakat sendiri, masyarakat magelang kabupaten termasuk dalam kategori masyarakat berkembang yang mana belum bisa mengikuti perkembangan teknologi yang berkembang dengat cepat terlebih halnya pengetahuan tentang e-tilang sangatlah minim di daerah tersebut, masih banyak masyarakat yang belum memiliki rekening atm dan belum mengerti tentang manfaat dari e-tilang yang memberikan kemudahan dalam pembayaran denda pelanggaran lalu lintas.

Kendala kedua adalah sosialisasi dari penerapan aplikasi etilang dalam proses penindakan pelanggaran lalu lintas serta pembayaran denda pelanggaran lalu lintas di Polres Magelang Kabupaten, pelaksanaan aplikasi e-tilang di Polres Magelang Kabupaten sudah berjalan 2 tahun 2017, namun dari hasil data jumlah Dakgar yang diperoleh, e-tilang masih minim di bandingkan tilang konvensional salah satu faktor nya adalah pengetahuan masyarakat tentang e-tilang yang ada di Polres Magelang.

Mekanisme pelayanan aplikasi e-tilang yang selama ini ada sesungguhnya tidak sesuai dengan pasal 4 huruf (b) Peraturan Kepala Korps Lalu Lintas Kepolisian Negara Republik Indonesia Nomor 6 Tahun 2018 yaitu efesiensi dan efektivitas, yaitu prosedur e-tilang harus sederhana, cepat, dan mudah dilaksanakan serta berdampak pada menurunya pelanggaran lalu lintas, namun fakta di lapangan prosedur etilang justru mempersulit penindakan pelanggaran lalu lintas karena perlunya dua kali kerja dalam tahap registrasi identitas pelanggar, hal ini di sebabkan petunjuk pelaksanaan tata cara penyelesaian pelanggaran lalu lintas yang memuat bahwa penyelesaian perkara pelanggaran lalu lintas harus disertai lembar surat tilang yang mana blangko No.14 pernyataan / keterangan tersangka / pelanggar bahwa telah melakukan pelanggaran 
lalu lintas jalan tertentu, dan kolom tanda tangan. Inilah mengapa perlunya pengisian blangko, sehingga dengan birokrasi yang memberatkan petugas kepolisian menjadi kurangnya motivasi untuk melakukan sosialisasi dan menggunakan aplikasi e-tilang sebagai sarana penindakan pelanggaran lalu lintas, hal ini dikemukakan oleh Aipda Budi Sartono di Pos Lantas Borobudur Kabupaten Magelang pada 1 Maret 2019.

Sarana prasarana, Aipda Budi Sartono juga menyampaikan dengan keterbatasan ATM Bank, membuat pelanggar merasa jauh dalam keterjangkauan pembayaran denda pelanggaran lalu lintas, EDC menjadi salah satu sarana yang sangat membantu dalam pembayaran denda tilang di tempat, namun ketersediaan di lapangan terhadap penyediaan EDC di setiap pos yang menjadi titik pelaksanaan penindakan pelanggaran lalu lintas belum tersedia secara menyeluruh, hanya terdapat 1 dari 6 pos yang berada di Pos Unit Turjawali Polres Magelang Kabupaten, hal ini di karenakan belum adanya kebijakan dan koordinasi antara instansi Bank Bri dan Polres Magelang Kabupaten terhadap permasalahan kekurangan sarana EDC tersebut.

\section{Simpulan}

Efektivitas aplikasi e-tilang dalam pembayaran denda pelanggaran lalu lintas di Polres Magelang terlihat belum efektif. Hasil penelitian yang berdasarkan temuan data di Kabupaten Magelang, aplikasi e- tilang di Polres Magelang belum memenuhi kelima indikator efektivitas suatu program sebagaimana dikemukakan oleh Stees dimana kelima indikator tersebut merupakan indikator produktivitas, kemampuan adaptasi kerja, kepuasan kerja, kemampuan berlaba dan pencarian sumber daya.

Faktor-faktor yang Mempengaruhi efektivitas aplikasi etilang dalam pembayaran denda pelanggaran lalu lintas di Polres Magelang Babupaten adalah: (1). Faktor Sumber Daya Manusia, dilihat dari aspek sumber daya manusia, dari sisi keduanya memiliki kekurangan yaitu, dari sisi Petugas Penindak Pelanggaran Lalu lintas yang belum bisa menerapkan aplikasi e-tilang secara simultan dan dilihat dari sisi masyarakat sendiri, masih banyak masyarakat yang belum memiliki rekening ATM dan belum mengerti tentang manfaat dari e-tilang; (2).Kurangnya sosialisasi dari penerapan aplikasi e-tilang dalam penindakan pelanggaran lalu lintas serta pembayaran denda pelanggaran lalu lintas di Polres Magelang Kabupaten sehingga penggunaan etilang masih minim di bandingkan tilang konvensional; (3).Mekanisme pelayanan aplikasi e-tilang yang selama ini ada sesungguhnya tidak sesuai dengan pasal 4 huruf (b) Peraturan Kepala Korps Lalu Lintas Kepolisian Negara Republik Indonesia Nomor 6 Tahun 2018 yaitu efesiensi dan efektivitas, yaitu prosedur e-tilang harus sederhana, cepat, dan mudah dilaksanakan serta berdampak pada menurunya pelanggaran lalu lintas, namun fakta di lapangan prosedur etilang justru mempersulit penindakan pelanggaran lalu lintas; dan (4). Sarana Prasarana, dengan keterbatasan ATM Bank yang membuat pelanggar merasa jauh dalam keterjangkauan pembayaran denda pelanggaran lalu lintas, EDC menjadi salah satu sarana yang sangat membantu dalam 
pembayaran denda tilang di tempat, namun ketersediaan di lapangan terhadap penyediaan EDC hanya terdapat 1 dari 6 pos yang berada di Pos Unit Turjawali Polres Magelang Kabupaten.

\section{Daftar Pustaka}

Buku:

Suteki, \& Taufani, G. (2018). Metodologi Penelitian Hukum (Filsafat, Teori Dan Praktik). Depok: PT. Raja Grafindo Persada.

\section{Jurnal:}

Chusminah, S., Haryati, R. A., \& Kristiani, D. (2018). Efektivitas Implementasi E-Tilang Kendaraan Bermotor Dalam Rangka Tertip Berlalu Lintas Pada Korps Lalu Lintas Polri. WIDYA CIPTA: Jurnal Sekretari dan Manajemen, Vol.2 No.2, pp. 217-224.

Junef, M. (2014). PERILAKU MASYARAKAT TERHADAP OPERASI

BUKTIPELANGGARAN (TILANG) DALAM BERLALU LINTAS. E-Journal WIDYA Yustisia, Vol.1 No.1, pp.52-60.

Rakhmadani, S. (2017). Analisis Penerapan E-Tilang Dalam Mewujudkan Good Governance Di Indonesia. Jurnal Sosial, Ekonomi dan Humaniora, Vol.7 No.3, pp. 663-671.

Salsabila, F. (2018). Inovasi Program Elektronik Tilang (E-Tilang) Dalam Meningkatkan Pelayanan Publik di Kepolisian Resort (POLRES) Kediri. Publika, Vol.6 No.2, pp.1-7.

Setiyanto, Gunarto, \& Wahyuningsih, S. E. (2017). Efektivitas Penerapan Sanksi Denda E-Tilang Bagi Pelanggar Lalu Lintas
Berdasarkan Undang-Undang Nomor 22 Tahun 2009 Tentang Lalu Lintas Dan Angkutan Jalan (Studi Di Polres Rembang). Jurnal Hukum Khaira Ummah, Vol.12 No.4, pp. 742-766.

\section{Peraturan Perundang-Undangan:}

Undang-Undang Dasar Negara Republik Indonesia Tahun 1945

Undang-Undang Nomor 2 Tahun 2002 tentang Kepolisian Negara Republik Indonesia

Undang-undang Nomor 22 Tahun 2009 tentang Lalu Lintas dan Angkutan Jalan 